\title{
Mesophilic and thermophilic biotreatment of BTEX-polluted air in reactors
}

Balsam T. Mohammad, María C. Veiga and Christian Kennes

Biotechnology and Bioengineering, Volume 97, Issue 6, pages 1423-1438, 15 August 2007

DOI: 10.1002/bit.2135

\begin{abstract}
This study compares the removal of a mixture of benzene, toluene, ethylbenzene, and all three xylene isomers (BTEX) in mesophilic and thermophilic $\left(50^{\circ} \mathrm{C}\right)$ bioreactors. In the mesophilic reactor fungi became dominant after long-term operation, while bacteria dominated in the thermophilic unit. Microbial acclimation was achieved by exposing the biofilters to initial BTEX loads of 2-15 $\mathrm{g} \mathrm{m}^{-3} \mathrm{~h}^{-1}$, at an empty bed residence time of $96 \mathrm{~s}$. After adaptation, the elimination capacities ranged from 3 to $188 \mathrm{~g} \mathrm{~m}^{-3} \mathrm{~h}^{-1}$, depending on the inlet load, for the mesophilic biofilter with removal efficiencies reaching $96 \%$. On the other hand, in the thermophilic reactor the average removal efficiency was $83 \%$ with a maximum elimination capacity of $218 \mathrm{~g} \mathrm{~m}^{-3} \mathrm{~h}^{-1}$. There was a clear positive relationship between temperature gradients as well as $\mathrm{CO}_{2}$ production and elimination capacities across the biofilters. The gas phase was sampled at different depths along the reactors observing that the percentage pollutant removal in each section was strongly dependant on the load applied. The fate of individual alkylbenzene compounds was checked, showing the unusually high biodegradation rate of benzene at high loads under thermophilic conditions (100\%) compared to its very low removal in the mesophilic reactor at such load $(<10 \%)$. Such difference was less pronounced for the other pollutants. After 210 days of operation, the dry biomass content for the mesophilic and thermophilic reactors were 0.300 and $0.114 \mathrm{~g} \mathrm{~g}^{-1}$ support, respectively, reaching higher removals under thermophilic conditions with a lower biomass accumulation, that is, lower pressure drop.
\end{abstract}

\section{Keywords:}

Biofiltration; alkylbenzene; thermophilic; waste gases; fungi; perlite. 


\section{Introduction}

Volatile organic compounds (VOC's) are of particular concern since they readily volatilize to the atmosphere and thus can be distributed over large regions leading to a population-wide exposure to those chemicals. They may be present in liquid, solid process and waste streams, and because of their relatively high vapor pressure, they are found predominantly in the atmosphere, causing different environmental problems, such as stratospheric ozone depletion, ground level ozone formation, global greenhouse effect, and toxic health effects (De Nevers, 1995; Hester and Harrison, 1995). From this, defined regulations concerning pollution issues have arisen to help both industrial and commercial sectors to reduce VOC emissions. Among available treatment approaches, biotechnological ones proved to be promising because they are reliable, simple and cost-effective compared to the physical and chemical processes, some of which require addition of chemicals, while expenditure of energy for physical treatment results in high capital and operational costs. Besides, biotechnological processes are clean, that is, environment friendly, and show good operation stability. Several bioreactor configurations have been developed and are being optimized nowadays for the removal of specific volatile organic and inorganic compounds from polluted air (Jin et al., 2005; Kennes and Veiga, 2001).

Application of the biofiltration technology to the treatment of VOCs has been investigated by a large number of researchers (Kennes and Veiga, 2001). The principal of biofilters is based on passing a polluted air stream through a porous packed bed on which pollutant-degrading microorganisms form an active biofilm layer on the surface of packing materials. The pollutant is transferred from the waste air stream into the biofilm due to the concentration gradient between the two phases, where it is degraded by the microorganisms. Performance of a biofilter depends on several factors as the selectivity of the microbial community, composition of the waste stream, operation parameters and design of the biofilter unit, among others (Elmrini et al., 2004).

Temperature is one of the crucial parameters that can affect the performance of the biofilter. In most laboratory research and industrial applications the biofilter unit has been run under mesophilic conditions $\left(15-30^{\circ} \mathrm{C}\right)$ (Van Lith et al., 1997). However, many industrial waste streams have temperatures higher than this range and additional cooling is required before processing to the biological treatment. Using thermophilic microorganisms would offer great cost savings and extend the applicability of biofilters. Few studies are available on the thermophilic treatment of waste gases. The effect of temperature in gas-phase bioreactors can be modeled by using an expression based on the Arrhenius equation (Jin et al., 2007). Although some authors observed a decrease in performance when switching from mesophilic to thermophilic conditions (Lu et al., 1999; Yoon and Park, 2002), several other biofiltration studies demonstrated higher removal rates in thermophilic biofilters in comparison to mesophilic ones. For instance, a higher removal rate for ethylacetate was achieved in a biofilter at $45-50^{\circ} \mathrm{C}$ compared to a mesophilic one (Deshusses et al., 1999). The same was recently observed in biotrickling filters treating mixtures of isobutyraldehyde and 2pentanone, reaching higher elimination capacities at $52^{\circ} \mathrm{C}$ than at $25^{\circ} \mathrm{C}$ (Luvsanjamba et al., 2007). In addition, Matteau and Ramsay (1997) reported toluene biofiltration at $48-50^{\circ} \mathrm{C}$ using an active compost of maple leaves and alfalfa as support materials. Additionally, some studies reported the degradation of BTEX compounds (Chen and Taylor, 1995), and alcohols (Al-Awadhi et al., 1989) by thermophilic microorganisms, as well as the co-treatment of methanol and $\alpha$-pinene in biotrickling filters maintained at temperatures between 40 and $70^{\circ} \mathrm{C}$ (Allen et al., 2000), and the treatment of ethanol and ammonia at $65^{\circ} \mathrm{C}$ (Heslinga and Van Groenestijn, 1997).

In this work, two biofilters operating under either mesophilic or thermophilic conditions were investigated in their ability to treat high loads of benzene, toluene, ethylbenzene, p-xylene, m- 
xylene, and o-xylene (BTEX). Those compounds are very important industrial solvents and common VOC pollutants. They are frequently involved in contaminated sites. Many BTEX gases are emitted into the atmosphere during manufacturing, transportation, use and disposal as well as site remediation. They are of particular concern because they are confirmed or suspected carcinogenic compounds (Chen and Taylor, 1995), and are classified as environmental priority pollutants by the EPA (Oh et al., 1994). Although some studies have demonstrated the use of biofilters for the treatment of petroleum and BTEX compounds (Kennes et al., 1996; Oh and Bartha, 1997; Veiga and Kennes, 2001; Wright et al., 1997), basically no reports are available on the performance of such biofilters under thermophilic conditions.

In this research, the effect of varying the inlet BTEX concentrations was investigated in terms of elimination capacity (EC) and removal efficiency under both mesophilic and thermophilic conditions. The fate of each pollutant was checked and appeared to be significantly affected by the operating temperature. In addition, this research provides the basis for future work on isolation of potential biocatalysts used for developing gas-phase bioreactors working under extreme conditions.

\section{Materials and Methods}

\section{Experimental Set-Up}

Two identical bench-scale biofilters were operated in parallel; the first one at mesophilic temperature (ambient conditions, approximately $20^{\circ} \mathrm{C}$ ), and the second one under thermophilic conditions (approximately $50^{\circ} \mathrm{C}$ ). Basically, the equipments used were the same as described previously (Kennes et al., 1996), except that the thermophilic biofilter was surrounded with a water jacket that maintained the temperature of the reactor at approximately $50^{\circ} \mathrm{C}$ by using a heating/re-circulating pump (Polyscience model 8012) maintained at a temperature higher by few degrees than the reactor. After 3 weeks of operation, mineral liquid medium was introduced into the thermophilic unit with a WatsonMarlow pump model 323E, because of drying problems in the packing material resulting from the high operational temperature. A low trickling rate $(300 \mathrm{~mL} \mathrm{dS1)}$ was then maintained to compensate for water losses. Similarly, liquid was sprayed regularly on the top of the mesophilic reactor in order to reach the same daily rate of liquid addition as in the thermophilic reactor. The biofilters were packed with $4 \mathrm{~L}$ perlite as inert support. The filter materials were sieved, retaining perlite particles with 4-6 mm diameter. Both biofilters were inoculated with the same non-adapted sludge obtained from a refinery, by filling each reactor with $2 \mathrm{~L}$ sludge diluted with mineral medium, and draining after $12 \mathrm{~h}$.

A compressed air stream was split into two flows. The major portion of air was humidified in a humidification chamber placed in a water bath adjusted to $37^{\circ} \mathrm{C}$, to ensure the air's relative humidity was more than $95 \%$. The minor air stream was bubbled through liquid BTEX in a flask to generate the contaminated air stream. All flow rates were regulated with flow meters (Brooks Sho-Rate II, model 1355). The two streams were mixed in an air chamber, and fed to the top of the reactor in a downflow mode.

The biofilters were operated at a constant empty bed residence time (EBRT) of $96 \mathrm{~s}$ and various inlet concentrations. During the start-up the inlet BTEX concentrations were kept low, around $0.3-0.4 \mathrm{~g} \mathrm{~m}^{-3}$, to allow gradual adaptation of the microorganisms. Upon reaching pseudo steady-state operation, the inlet BTEX concentration (hence inlet load) was increased gradually. Mineral medium (2 L) was supplied at the top of the column three times per week and drained off after half an hour. The medium had the following composition per liter of deionized water, $0.5 \mathrm{~g} \mathrm{~K}_{2} \mathrm{HPO}_{4}, 0.1 \mathrm{~g} \mathrm{MgSO}_{4} * 7 \mathrm{H}_{2} \mathrm{O}$, $4.5 \mathrm{~g} \mathrm{KH}_{2} \mathrm{PO}_{4}, 2 \mathrm{~g} \mathrm{NH} 4 \mathrm{Cl}$, and $2 \mathrm{~mL}$ trace elements and vitamin solutions (Kennes et al., 1996). 


\section{Analytical Methods}

Duplicate gas samples were analyzed on an HP 5890 gas chromatograph equipped with a 50m TRACER column and a flame ionization detector (FID) at $250^{\circ} \mathrm{C}$. The flow rates were $30 \mathrm{~mL}$ $\min ^{-1}$ for $\mathrm{H}_{2}$ and $300 \mathrm{~mL} \mathrm{m^{-1 }}$ for air. Helium was used as carrier gas at a flow rate of $2 \mathrm{~mL}$ minS1. The initial temperature was $60^{\circ} \mathrm{C}$, followed by heating at a rate of $2^{\circ} \mathrm{C} \min ^{-1}$ to $80^{\circ} \mathrm{C}$, then heating at $1^{\circ} \mathrm{C} \mathrm{min}^{-1}$ to a final temperature of $96^{\circ} \mathrm{C}$. For sampling, $25 \mathrm{~mL}$ of gas was taken with a gastight syringe.

Carbon dioxide was analyzed in triplicate with a gas chromatograph HP 5890 equipped with a thermal conductivity detector (TCD). $\mathrm{CO}_{2}$ concentration was determined at an injection temperature of $90^{\circ} \mathrm{C}$, an oven temperature of $25^{\circ} \mathrm{C}$ and with the TCD at $100^{\circ} \mathrm{C}$.

At different time intervals, packing samples were gently removed from both biofilters. For the estimation of the dry biomass weight, around (3-4) g of each sample was placed in an oven at $90^{\circ} \mathrm{C}$ for $12 \mathrm{~h}$ until constant weight was obtained. After drying, moisture content in the packing material was determined by measuring the weight loss. Those data are not shown in this study, although they were used for frequent monitoring of moisture in the biofilters. Afterwards, dried samples were placed in a furnace at $550^{\circ} \mathrm{C}$ for $4 \mathrm{~h}$, and the dry biomass content was determined by measuring the weight loss. After each biomass sampling, the same quantity of fresh perlite grains was added to compensate for the withdrawn samples. Protein contents were determined by extracting samples of support material and by mixing $1 \mathrm{~g}$ of packed support with $5 \mathrm{~mL} \mathrm{NaOH}(1 \mathrm{M})$. The samples were treated with ultrasounds for 30 min and centrifuged (5,000 rpm for $10 \mathrm{~min}$ ). Protein in the solution was quantified using the Bradford method (Bradford, 1976) with a bovine serum albumin standard.

$\mathrm{pH}$ was measured with a Crison model GLP $22 \mathrm{pH}$-meter connected to an Ingold electrode. The relative humidity was checked daily with a Lufft C210 sensor. Temperature profiles for both biofilters were measured by common thermometers with a range of -5 to $150^{\circ} \mathrm{C}$. Pressure drop was measured with a U tube-manometer filled with water.

Scanning electron microscopy (SEM) was used to visualize the perlite particles colonized with microbial populations. Samples were subjected to drying for $24 \mathrm{~h}$, placed on metallic stub and covered with a gold layer in a Blazers SCD-004 sputter coater, to increase their electrical conductivity. The micrographs were taken using a JEOL JSM-6400 scanning electron microscope working at a voltage of $20 \mathrm{kV}$ and a working distance of $15 \mathrm{~mm}$, and Oxford Instrument EDX equipment.

\section{Results and Discussion}

\section{Overall BTEX Removal and Reactor Performance}

One of the important parameters affecting biofilter performance is the inlet pollutants concentrations; therefore a gradual concentration increase during the initial phases of reactor operation is important for proper microbial growth and development. The two biofilters were fed initially relatively low inlet BTEX concentrations of $0.3-0.4 \mathrm{~g} \mathrm{~min}^{-1}$. Consequently, the two biofilters were run at this low concentration until steady state conditions were achieved.

The EBRT was kept constant and the overall pollutants inlet concentration was gradually increased, so the load changed proportionally and the performances of the biofilters were recorded. Results shown in Figure $1 \mathrm{~A}$ and $\mathrm{B}$ indicate that the acclimation period for both biofilters was around one month. This long period was expected due to the use of non adapted sludge for inoculation. The same observation was made by van Groenestijn and Liu (2002) in their study of $\alpha$-pinene removal and by Dehghanzadeh et al. (2005) during styrene biofiltration. Conversely, a quite faster start-up of only a few hours can be obtained when using adapted inocula or specialized microorganisms (Veiga and Kennes, 2001). Also, mixing the filter bed with high concentrations of pollutants and necessary nutrients allows increasing 
the mass and number of microbes specific for the pollutant, thus shortening the acclimation period (Torkian et al., 2003).

During the operation, the relative humidity of the air stream was kept around 95\% except during the first month of start-up and between days 134 and 191 due to malfunctioning of the humidification system, resulting in a drop of the relative humidity down to $79 \%$. Also, from day 125 of operation the two biofilters were subjected to a shut down period of 10 days and one month for the mesophilic and thermophilic biofilter, respectively. After this shut down an acclimation period was required by operating the systems at low BTEX load. This period lasted approximately 10 days and 1 week for the mesophilic and thermophilic reactors, correspondingly. This is considered longer than the rapid recovery of a fungal biofilter reported by Woertz et al. (2001) which achieved 96\% removal efficiency within $1 \mathrm{~h}$ after 8.5 day shut down. Similarly, $30 \mathrm{~h}$ was needed in a biotrickling filter treating toluene to reach $70 \%$ recovery (Cox et al., 1997), and $3.5 \mathrm{~h}$ in a fungal biofilter treating a gas phase solvent mixture (Moe and Qi, 2004). It is hypothesized that the response of a biofilter after a shut down period depends on the composition of the microbial populations, the duration of the starvation period, the nature of pollutants applied, and the loading rate (Characklis et al., 1991). 
A

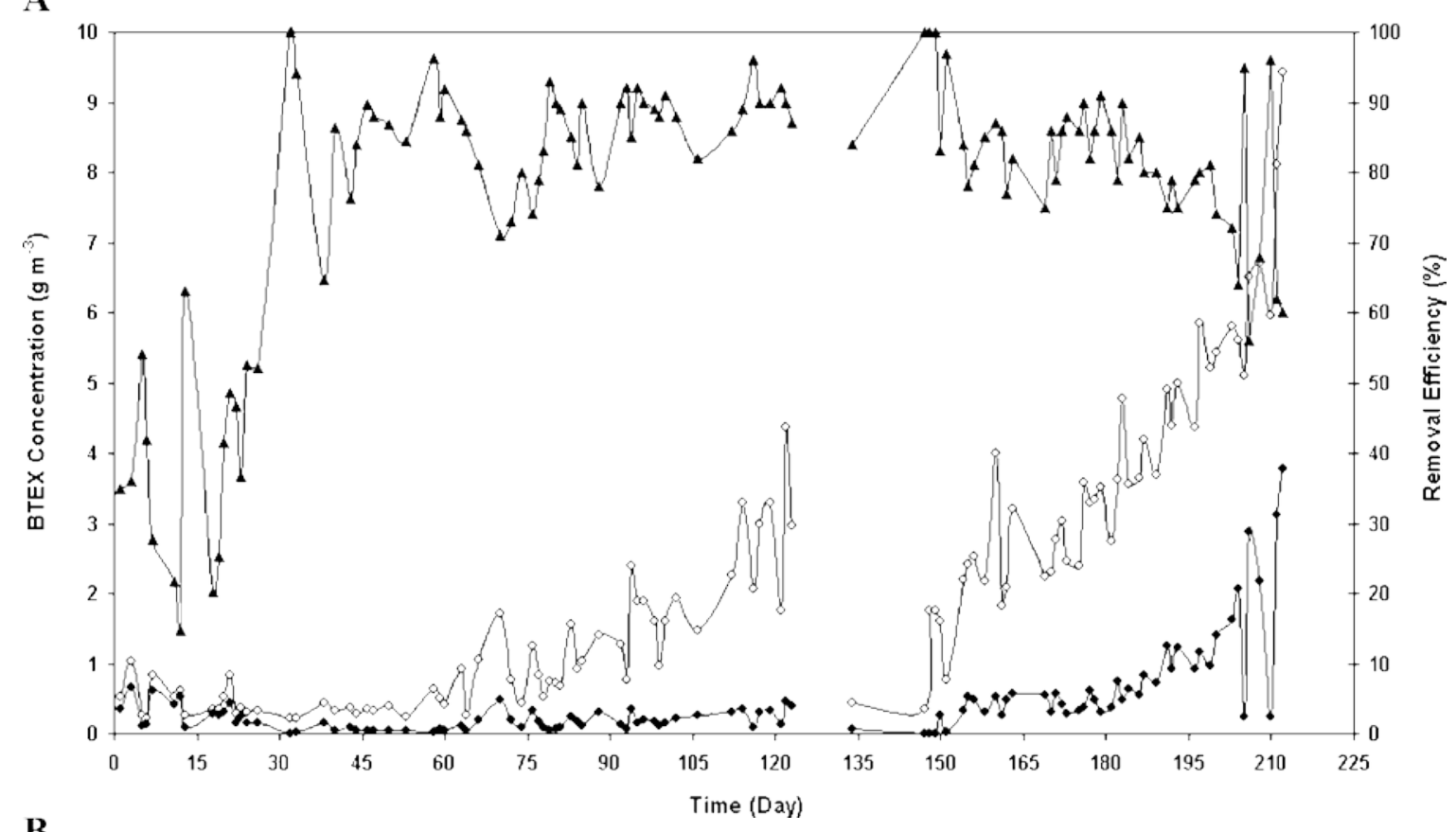

B

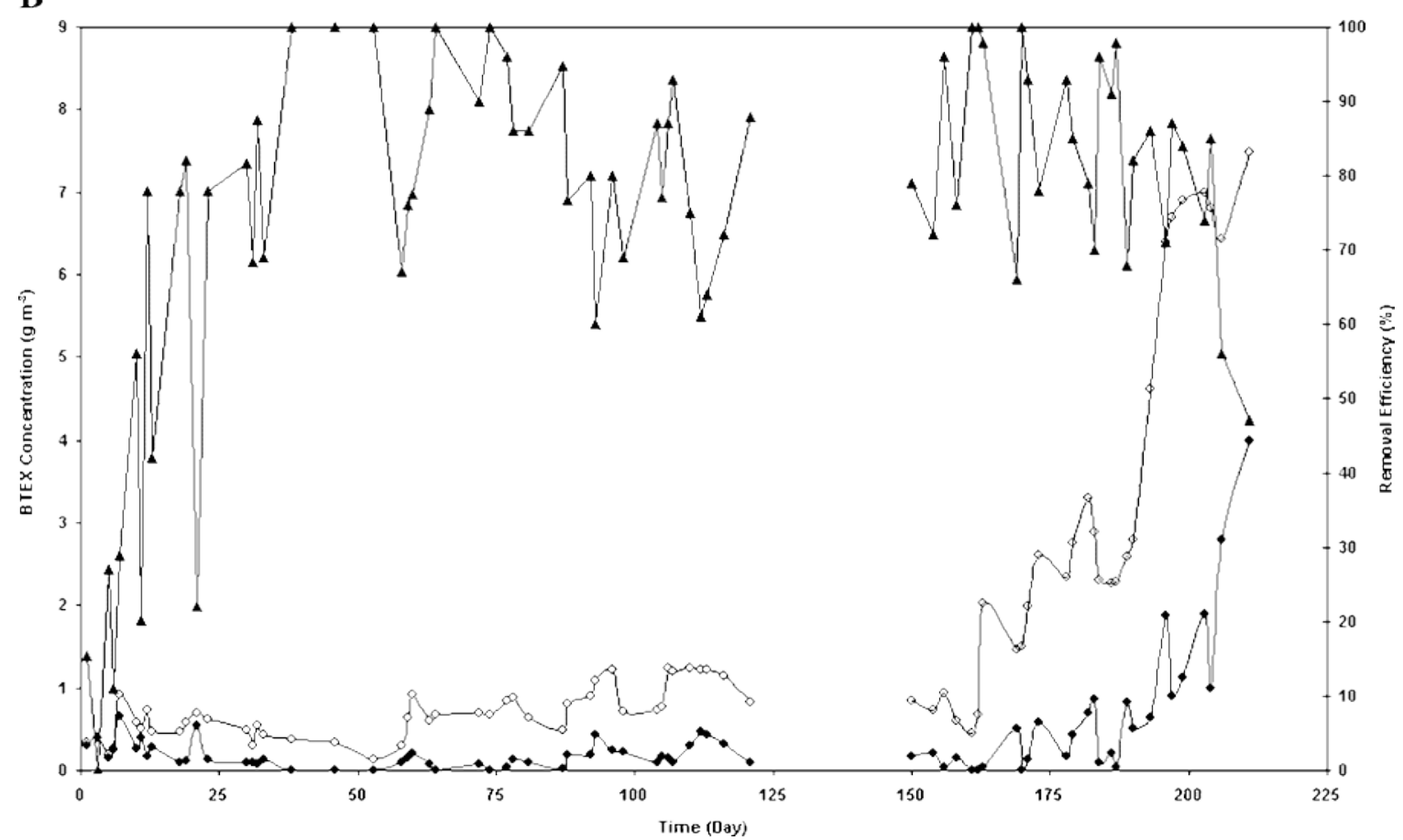

Figure 1. A: BTEX inlet concentration $(*)$, outlet concentration $(*)$, and removal efficiency $(\sim)$ for the mesophilic biofilter. B: BTEX inlet concentration $(*)$, outlet concentration $(*)$, and removal efficiency $(\sim)$ for the thermophilic biofilter.

After the startup period, the inlet load was increased between approximately 11 and $304 \mathrm{~g} \mathrm{~m}^{-3}$ $\mathrm{h}^{-1}$ (Inlet concentrations $\frac{1}{4} 40.3$ and $8 \mathrm{~g} \mathrm{mS3}$ ) for the mesophilic reactor, and between 12 and $256 \mathrm{~g} \mathrm{~m}^{-3} \mathrm{~h}^{-1}$ (Inlet concentrations $=0.32$ and $7 \mathrm{~g} \mathrm{~m}^{-3}$ ) for the thermophilic one. Figure 1A represents changes in BTEX removal efficiency during 212 days of operation for the mesophilic biofilter. After an acclimation period of 1 month, the inlet load was raised stepwise to $66 \mathrm{~g} \mathrm{~m}^{-3} \mathrm{~h}^{-1}$ (from day 33 to day 148 of operation), an average removal efficiency of $86 \pm 9.7 \%$ was achieved during that time. When BTEX inlet load was further increased to reach $354 \mathrm{~g} \mathrm{~m}^{-3} \mathrm{~h}^{-1}$ on day 212 of operation, the average removal efficiency obtained from day 149 to day 212 was $82 \pm 6.8 \%$. On the other hand, an average removal efficiency of $82.5 \pm 12 \%$ 
was obtained for the thermophilic biofilter during days 30 to 211 of operation. The highest EC of $218 \mathrm{~g} \mathrm{~m}^{-3} \mathrm{~h}^{-1}$ has been obtained for the thermophilic biofilter with a corresponding RE of $85 \%$. On the other hand, the maximum EC reached for the mesophilic biofilter was $188 \mathrm{~g} \mathrm{~m}^{-3}$ $\mathrm{h}^{-1}$ with a RE of $62 \%$. As expected, increasing the inlet BTEX load for both biofilters reduced the removal efficiency. For example, increasing the inlet BTEX load applied to the mesophilic reactor from 120 to $304 \mathrm{~g} \mathrm{~m}^{-3} \mathrm{~h}^{-1}$ (Inlet concentrations=3.2-8 $\mathrm{g} \mathrm{m}^{-3}$ ) decreased the removal efficiency from 87 to $62 \%$. The same phenomenon was observed for the thermophilic unit, in which increasing the inlet load up to $240 \mathrm{~g} \mathrm{~m}^{-3} \mathrm{~h}^{-1}$ (Inlet concentration $=6.4 \mathrm{~g} \mathrm{~m}^{-3}$ ) caused a drop in removal efficiency down to $70 \%$ (Fig. 1B). The increase in the inlet concentration enhanced the transfer rate of pollutant to the biofilm since the residence time for the gas in the filter bed was constant (Jorio et al., 1998).

In this work, the thermophilic biofilter operated at a temperature of $50^{\circ} \mathrm{C}$ showed effectiveness in treating BTEX gases at high loads. Little information exists on the treatment of VOCs at temperatures higher than $40^{\circ} \mathrm{C}$, although several studies show that a small increase of the temperature within the mesophilic range usually improves pollutant removal in biofilters and biotrickling filters (Arnold et al., 1997; Lu et al., 1999). Moreover, several studies reported a decrease in removal efficiency when the biofilter was operated at thermophilic temperature. This could be due to the fact that the inoculated and dominant microorganisms were not adapted to high temperatures, and to the reduced tolerance to substrate toxicity at high temperatures. The microbial populations developing under thermophilic conditions could also be more sensitive to high VOC loads. Yoon and Park (2002) studied the biofiltration of VOCs in a peat packed biofilter, and they concluded that the removal efficiency was the highest at $32^{\circ} \mathrm{C}$ and decreased at $45^{\circ} \mathrm{C}$. These findings are consistent with those of other researches, which indicate that microbial activity was optimal at $22-35^{\circ} \mathrm{C}$ (Leson and Winer, 1991) or that VOC degradation was inhibited at temperatures above $40^{\circ} \mathrm{C}$ (Lu et al., 1999). On the other hand, successful removal of ethanol and $\alpha$-pinene in a biotrickling filter maintained between 40 and $70^{\circ} \mathrm{C}$ has been reported (Van Lith et al., 1997), and Cox et al. (2001) observed the same efficiency during thermophilic and mesophilic biofiltration of ethanol vapors.

Data of EC versus load yield important information to describe the performance of the biofilter and to allow for comparison between different biofilter units. The BTEX mixture elimination capacities as a function of inlet load of both biofilters are plotted in Figure 2. Experimental results show a rather linear relationship between EC and BTEX loading rate for both biofilters at loads below approximately $150 \mathrm{~g} \mathrm{~m}^{-3} \mathrm{~h}^{-1}$. Data were more scattered at higher organic loadings. The maximum EC of total BTEX mixture reached in this study was $188 \mathrm{~g}$ $\mathrm{m}^{-3} \mathrm{~h}^{-1}$ at an inlet load of $304 \mathrm{~g} \mathrm{~m}^{-3} \mathrm{~h}^{-1}$ for the mesophilic unit. The thermophilic biofilter removed $218 \mathrm{~g} \mathrm{~m}^{-3} \mathrm{~h}^{-1}$ at an inlet BTEX load of $255 \mathrm{~g} \mathrm{~m}^{-3} \mathrm{~h}^{-1}$. Other authors usually reached lower values. For example, Kamarthi and Willingham (1994) used a coarse sand and carbon media, respectively under mesophilic conditions. The maximum elimination

capacities reached were $30 \mathrm{~g} \mathrm{~m}^{-3}$ coarse sand $\mathrm{h}^{-1}$ and $44 \mathrm{~g} \mathrm{~m}^{-3}$ carbon media $\mathrm{h}^{-1}$. Moreover, a maximum EC of $85 \mathrm{~g} \mathrm{~m}^{-3} \mathrm{~h}^{-1}$ was obtained during TEX mixture biofiltration carried out by Gabaldon et al. (2006), while values of $70 \mathrm{~g} \mathrm{TEX} \mathrm{m}^{-3} \mathrm{~h}^{-1}$ and $120 \mathrm{~g} \mathrm{TEX} \mathrm{m}^{-3} \mathrm{~h}^{-1}$ were reported in other, previous studies (Kennes et al., 1996; Veiga and Kennes, 2001). 


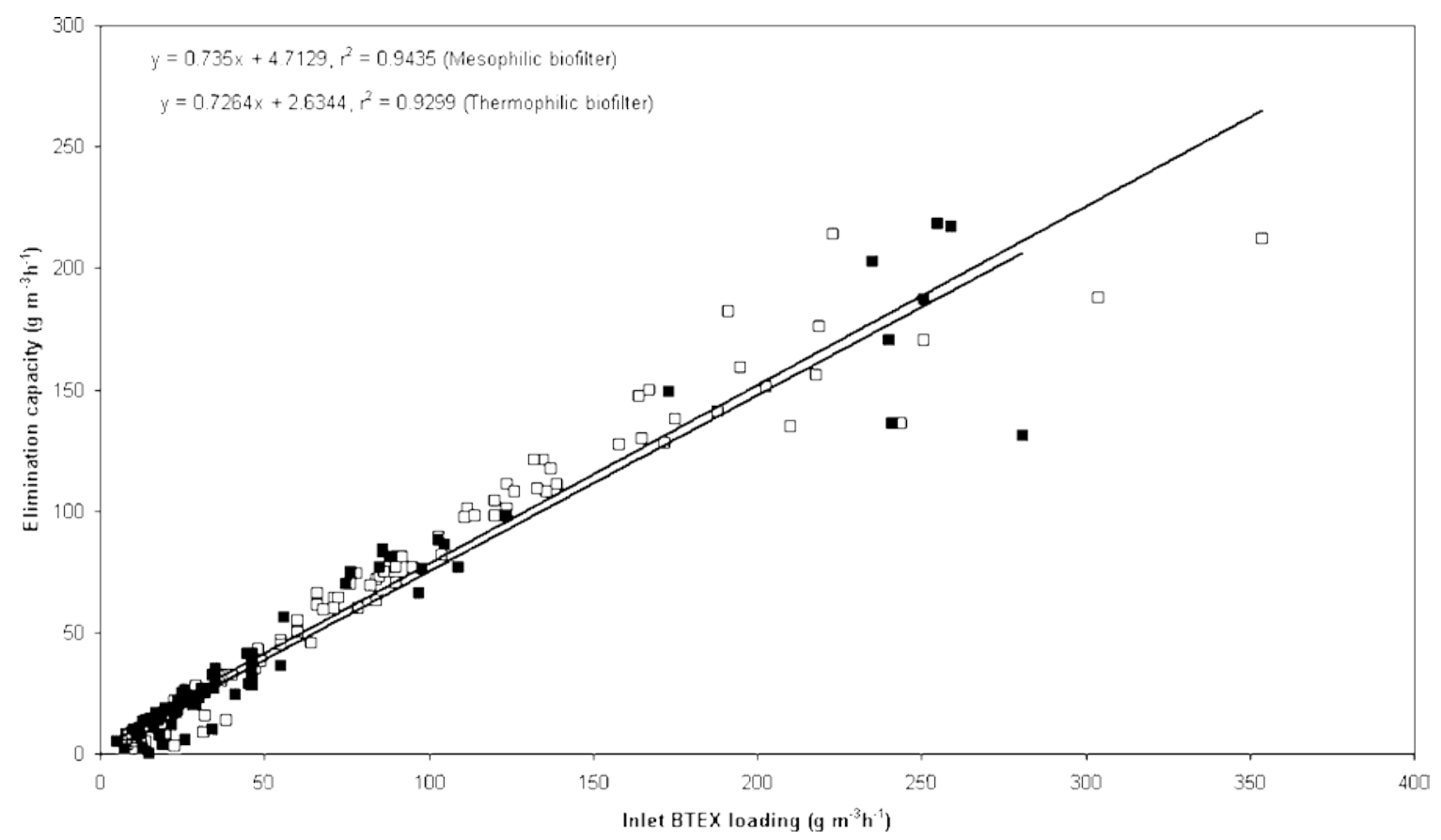

Figure 2. BTEX mixture elimination capacity versus inlet load for the mesophilic (\&) and thermophilic biofilters (\&).

\section{Individual Compounds Removal}

Figure $3 \mathrm{~A}$ and $\mathrm{B}$ shows the individual removal efficiency for each compound under different BTEX loadings ranging from 13 to $218 \mathrm{~g} \mathrm{~m}^{-3} \mathrm{~h}^{-1}$ for the mesophilic reactor, and from 14 to $240 \mathrm{~g} \mathrm{~m}^{-3} \mathrm{~h}^{-1}$ for the thermophilic reactor. As can be seen, the effect of temperature on the removal efficiency of BTEX compounds varies from one compound to another. The presence of one specific BTEX compound can either stimulate or inhibit the biodegradation of others (Alvarez and Vogel, 1991). Furthermore, the influence of temperature on the specific mass transfer and partition (Henry) coefficient could have definite influences on reactor performance, and imposed conditions may cause overall performance to deviate from literature data (Alvarez and Vogel, 1991; Deeb and Alvarez-Cohen, 1999). It can be seen from both figures that increasing the BTEX load decreased the removal efficiency for most compounds in both units. Benzene and toluene were the only compounds for which their removal efficiencies were not affected significantly by this load increase for the reactor operating under thermophilic temperature. On the other hand, increasing the BTEX load from 37 to $70 \mathrm{~g} \mathrm{~m}^{-3} \mathrm{~h}^{-1}$ caused a significant drop in benzene's removal efficiency for the mesophilic biofilter (from 100 to 30\%). Also, other authors reported that the removal efficiency of benzene was lower than toluene during biofiltration using waste compost (Webster et al., 1995). Oritz et al. (1998) reported that the mesophilic removal efficiency of benzene was the lowest among BTX compounds contained in gasoline vapor. This could be due to its high toxicity since the threshold limit value for benzene is much lower than for other benzenecompounds. Conversely, toluene and ethylbenzene removal efficiencies were the highest of all six pollutants under mesophilic condition in the present study, with a constant value in the range of $90-100 \%$. This value dropped to $80 \%$ at a BTEX load as high as $218 \mathrm{~g} \mathrm{~m}^{-3} \mathrm{~h}^{-1}$. A possible explanation for the enhanced removal efficiency for benzene and other compounds under higher temperature may be based on the higher enzymatic reaction rates at elevated temperature. At thermophilic temperatures the biofilm would be rapidly depleted of residual BTEX compounds, thus avoiding the negative competitive effects found at mesophilic temperatures (Strauss et al., 2004). The significantly higher removal of benzene (100\%), at high loads, under thermophilic conditions compared to mesophilic ones $(<10 \%)$ is also significant. It is worth mentioning that the Henry coefficient for benzene increases from about 0.18 to 0.58 when increasing the temperature from 20 to $50^{\circ} \mathrm{C}$, while it increases more rapidly 
for toluene, that is, from $0.21\left(20^{\circ} \mathrm{C}\right)$ to $0.79\left(50^{\circ} \mathrm{C}\right)$. The availability of benzene in the liquid phase, that is, biofilm, could thus be higher at high temperature than for an alkylbenzene as toluene. It is known that complicated substrate interactions are likely to occur when studying biodegradation of monoaromatic compounds in mixtures despite similarities in chemical structures depending also on the microbial populations developing under different temperatures. The temperature may affect the metabolism and the rate of pollutant degradation.

A

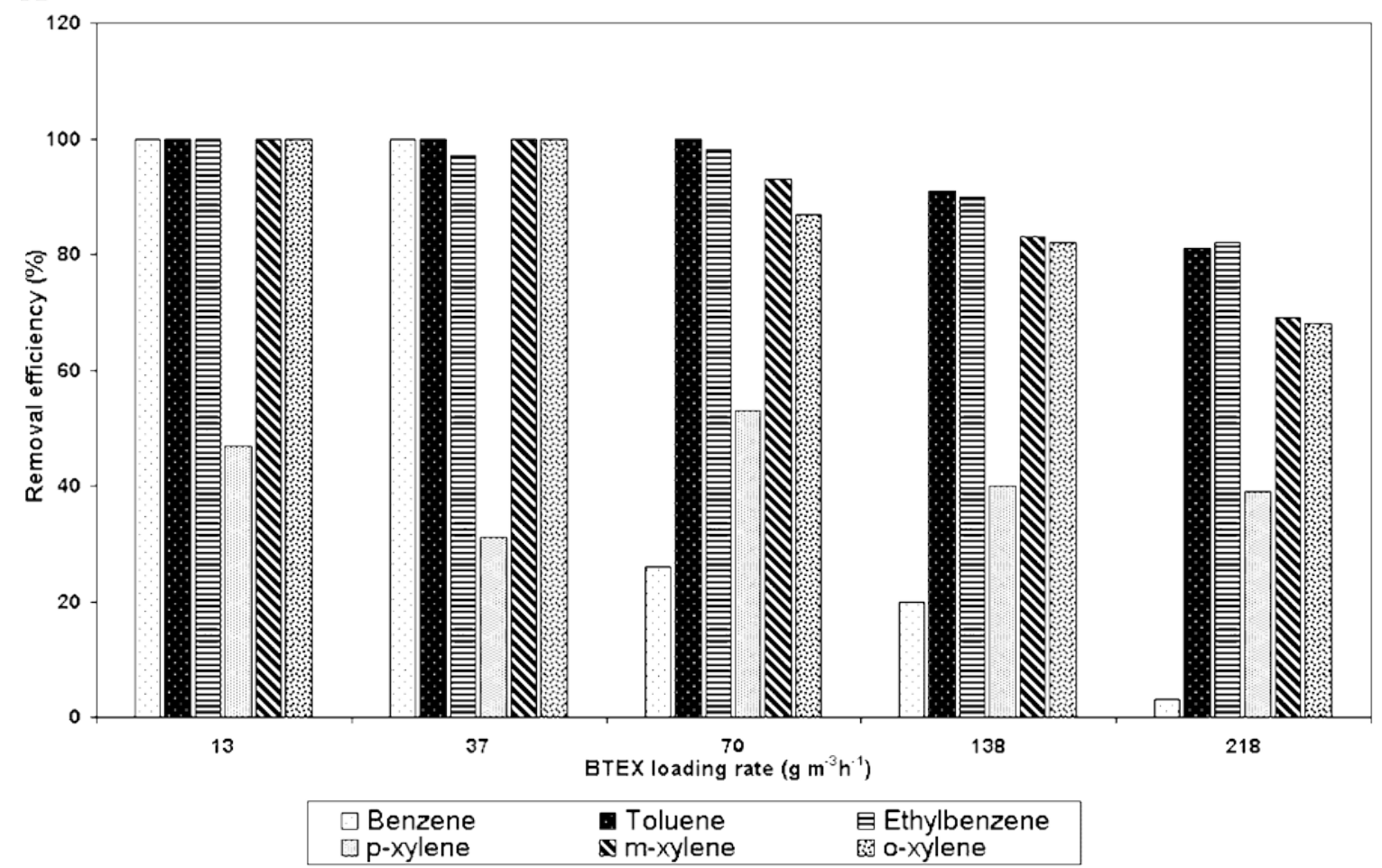

B

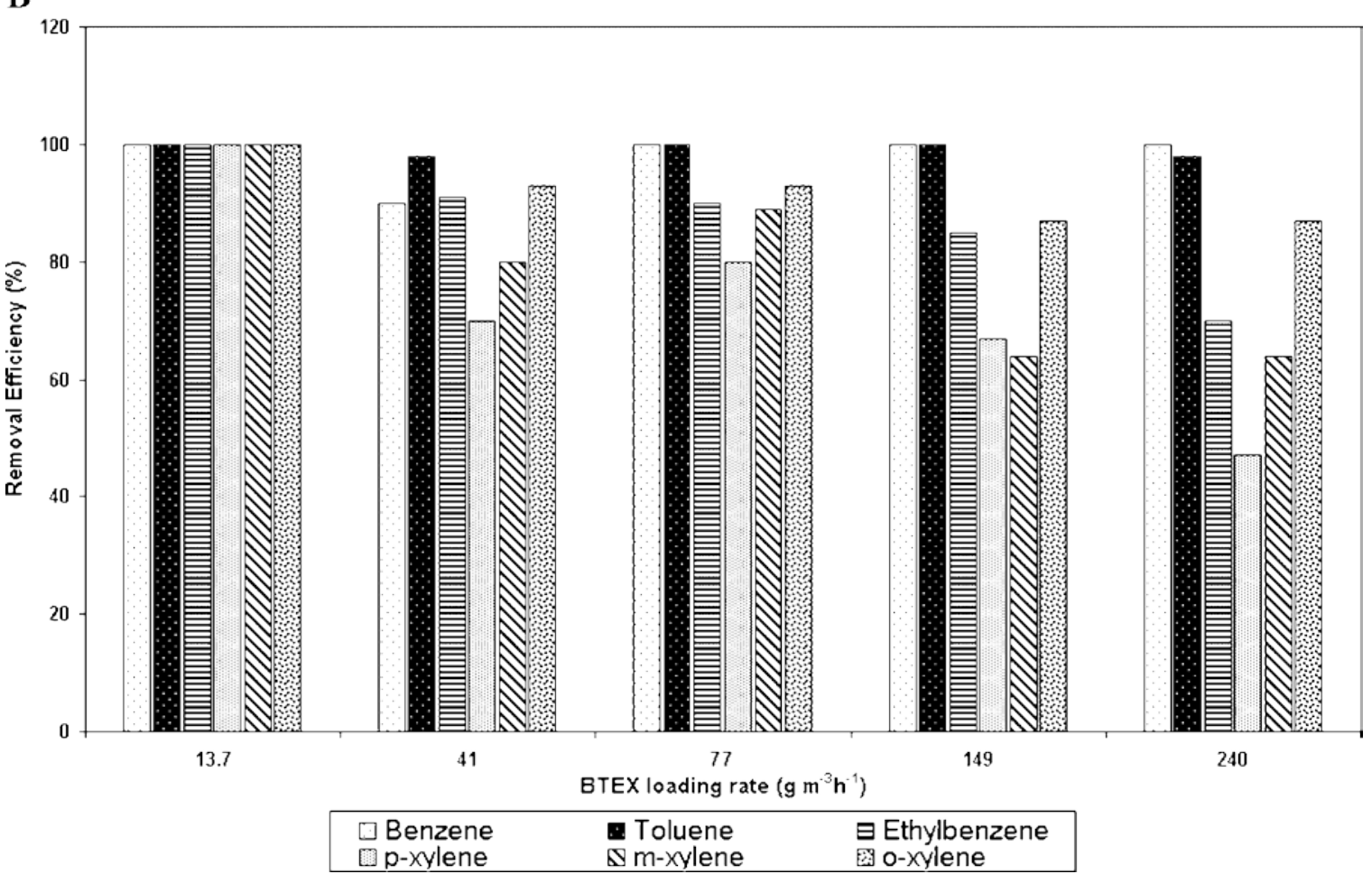

Figure 3. A: Removal efficiency for individual BTEX compounds under mesophilic conditions. B: Removal efficiency for individual BTEX compounds under thermophilic conditions. 
Strauss et al. (2004) studied both the positive and negative effects of toluene, individual BEX compounds and BEX compounds in paired mixtures with toluene using mesophilic and thermophilic biofilters. They found that under mesophilic conditions toluene removal was inhibited by the presence of other BEX compounds, while toluene enhanced their removal efficiency. This suggests that the removal efficiency of BEX compounds occurred at the expenses of toluene, mainly due to the similarities in their catabolic

pathways and enzymatic systems (Smith, 1990). In contrast, under thermophilic conditions both toluene and BEX removal improved when paired with toluene, except for p-xylene. In our study also, among xylenes isomers p-xylene degradation was the lowest compared to the other compounds fed to the mesophilic reactor, with a corresponding removal of $47-40 \%$ at VOC loads of 12.9 and $138 \mathrm{~g} \mathrm{~m}^{-3} \mathrm{~h}^{-1}$, respectively (Fig. 3A), while the thermophilic reactor exhibited 100\% RE for the same compound at an initial BTEX load of $13.7 \mathrm{~g} \mathrm{~m}^{-3} \mathrm{~h}^{-1}$ followed by $33 \%$ reduction in the RE of p-xylene when the load was increased to $149 \mathrm{~g} \mathrm{~m}^{-3} \mathrm{~h}^{-1}$ (Fig. 3B).

In general, the increase of BTEX load caused a decrease of the removal efficiency for the three xylene isomers in both units. The difference between m-xylene and o-xylene was not very significant under mesophilic condition, whereas at thermophilic condition o-xylene was more efficiently degraded under all loads applied. In our study the biodegradability of xylene isomers ranked as follows under thermophilic condition: o-xylene $>\mathrm{m}$-xylene $>$ p-xylene. These results agree with the data obtained by Strauss et al. (2004) using a toluene acclimatized biofilter. The reason for this behavior could be related to the varying affinity of the degrading microorganisms towards the chemical structure of each isomer. The rank obtained in this work was different from that reported by some other authors, reporting that oxylene was less biodegradable than other isomers (Bibeau et al., 2000). In addition, it is worth mentioning that the biodegradation pathways for o-xylene and m-xylene have been found to be similar, but different from the catabolic pathway for p-xylene (Smith, 1990).

In several biofiltration studies, the removal of xylenes was always less efficient in comparison with other pollutants. Kennes et al. (1996) reported lower elimination capacities of o-xylene $\left(63.6 \mathrm{~g} \mathrm{~m}^{-3} \mathrm{~h}^{-1}\right)$ in comparison to toluene and ethylbenzene with a corresponding value of 72.9 and $85.2 \mathrm{~g} \mathrm{~m}^{-3} \mathrm{~h}^{-1}$, respectively. Furthermore, analysis of results obtained in another study on the treatment of high concentrations of toluene and xylene, up to $115 \mathrm{~g} \mathrm{~m}^{-3} \mathrm{~h}^{-1}$, in a pilot scale biofilter indicated that xylene biodegradation was less efficient than toluene biodegradation (Jorio et al., 1998). Moreover, a similar trend of easier degradation of ethylbenzene and toluene than o-xylene was later also observed by others (Gabaldon et al., 2006). In terms of elimination capacities, linear relationships were observed between biofilters loading rate and EC for benzene, toluene, ethylbenzene, p-xylene, m-xylene, and o-xylene (Fig. 4A and B). For the mesophilic biofilter, the slope for toluene (0.89) was the highest among other compounds tested, while the slope of benzene was the lowest (0.19), and the correlation coefficient was very low for benzene $\left(r^{2}=0.23\right)$. On the contrary, under high temperature, the benzene's slope was much higher (0.84) compared to the mesophilic condition, while oxylene's slope was the highest (0.87) among all compounds for the thermophilic biofilter, followed by benzene. In this work, the maximum ECs of toluene in BTEX were 41 and $69 \mathrm{~g}$ $\mathrm{m}^{-3} \mathrm{~h}^{-1}$ under ambient and high temperature, respectively. Ethylbenzene's removal rate was rather similar in both biofilters, that is, 47 and $42 \mathrm{~g} \mathrm{~m}^{-3} \mathrm{~h}^{-1}$ for the mesophilic and thermophilic reactors, correspondingly. The benzene removal rate increased six times at higher temperature. For instance it improved from $3 \mathrm{~g} \mathrm{mS3} \mathrm{hS1} \mathrm{at} \mathrm{ambient} \mathrm{temperature} \mathrm{up} \mathrm{to} 18 \mathrm{~g} \mathrm{~m}^{-}$ ${ }^{3} \mathrm{~h}^{-1}$ under thermophilic condition. On the other hand, working at high temperature decreased the removal rate of o-xylene by half, to reach $26 \mathrm{~g} \mathrm{~m}^{-3} \mathrm{~h}^{-1}$ in the thermophilic biofilter. 

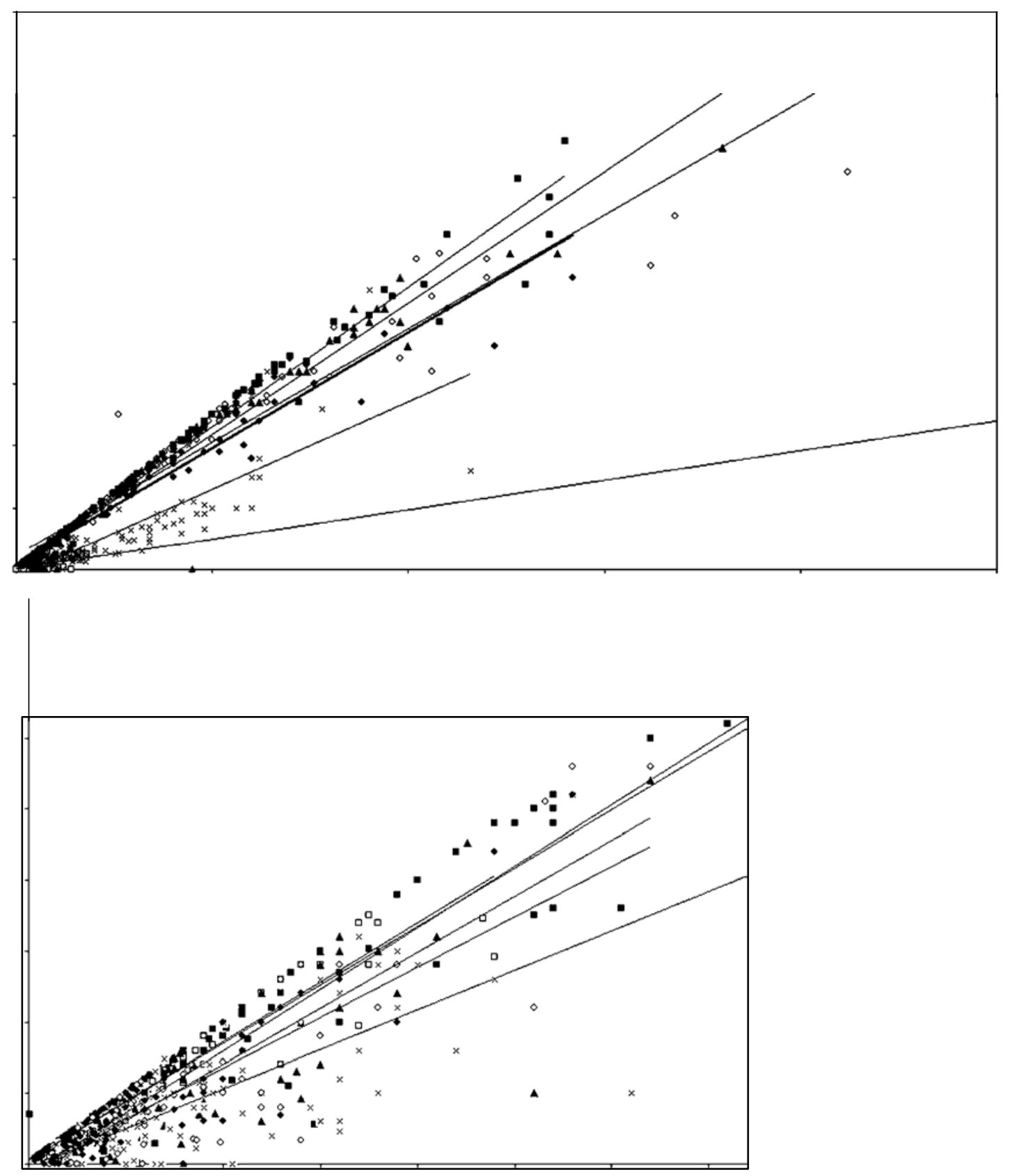

oFigure 4. A: BTEX elimination capacity versus inlet load of benzene $(\boldsymbol{Q}$, toluene $\boldsymbol{(})$. ethylbenzene $(\boldsymbol{Q} \cdot \mathrm{p}$-xylene () . m-xylene $(\boldsymbol{O}$. and o-xylene

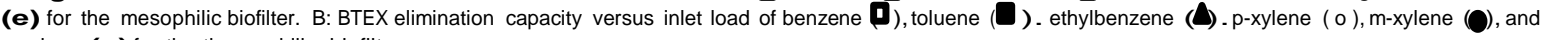
o-xylene (e) for the thermophilic biofilter.

Removal Profiles at Different Biofilter Depths

For better understanding the BTEX elimination mechanism within the reactor the concentration profile at different heights was measured for both biofilters under different operating loads. Four sampling ports were located across the bed height with $20 \mathrm{~cm}$ distance between each. The ratio between the outlet BTEX concentration and the inlet concentration at selected initial loads is presented in Figure 5. These results were achieved under steadystateconditions and show that in both biofilters a stratification of the removal efficiency along the biofilter height was observed. For example, at an inlet load of $18.3 \mathrm{~g} \mathrm{~m}^{-3} \mathrm{~h}^{-1}$ (Inlet concentration $=0.488 \mathrm{~g} \mathrm{~m}^{-3}$ ) for the thermophilic biofilter approximately $66 \%$ of the inlet BTEX mixture was degraded in the biofilter between the inlet port and the first $20 \mathrm{~cm}$, whereas 29\% was degraded between 20 and $60 \mathrm{~cm}$. The profile shows an exponential decrease, which is consistent with the results obtained by other researchers for this range of 
concentrations in biofilters (Dehghanzadeh et al., 2005). Additionally, when the inlet load increased to $88 \mathrm{~g} \mathrm{mS3} \mathrm{hS1} \mathrm{(Inlet} \mathrm{concentration=2.337} \mathrm{g} \mathrm{m}^{-3}$ ), the BTEX compounds were degraded over the complete height of the thermophilic column with uniform degradation rates of nearly 30\% achieved at the different height levels. A further inlet load increase up to $255 \mathrm{~g}$ $\mathrm{m}^{-3} \mathrm{~h}^{-1}$ caused a significant deterioration in the upper section's performance, where only $13 \%$ of the inlet BTEX compounds were removed in the first $40 \mathrm{~cm}$. A similar behavior was observed for the mesophilic reactor, where feeding the unit with an inlet load of $27.5 \mathrm{~g} \mathrm{~m}^{-3} \mathrm{~h}^{-1}$ (Inlet concentration $1 / 40.732 \mathrm{~g} \mathrm{~m}^{-3}$ ), resulted in about 33\% of the BTEX compounds being degraded in the biofilter height between 0 and $20 \mathrm{~cm}$ (inlet zone), in comparison to $3 \%$ being only removed at the same height at an inlet BTEX load of $165 \mathrm{~g} \mathrm{~m}^{-3} \mathrm{~h}^{-1}$ (Inlet concentration4.4 $\left.\mathrm{g} \mathrm{m}^{-3}\right)$.

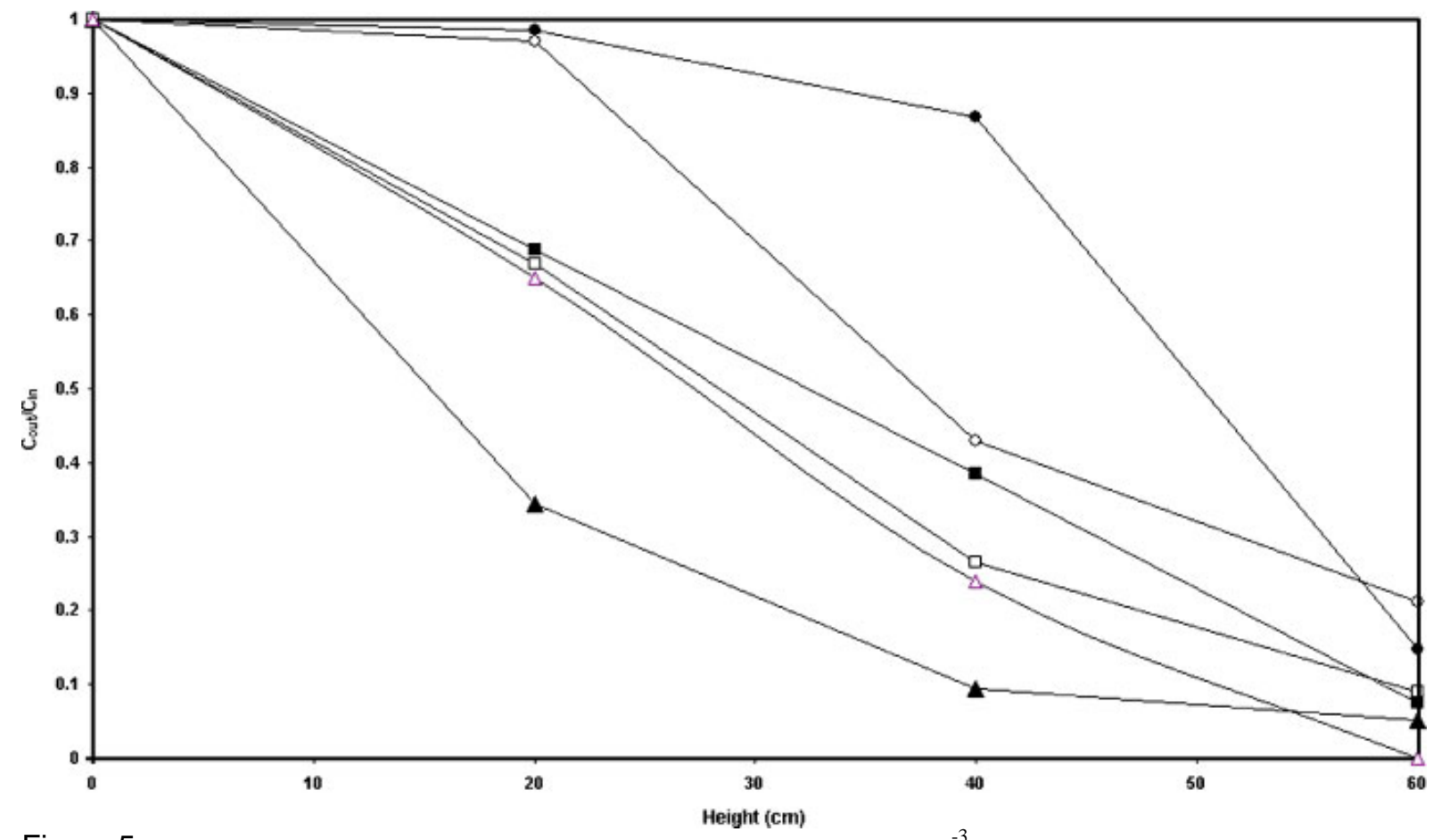

Figure 5. BTEX removal profile for an inlet concentration of 0.732 (), $1.754 \Delta)$, and $4.41 \mathrm{~g} \mathrm{~m}^{-3}$ (o) for the mesophilic biofilter, and for an inlet concentration of $0.488\left(\boldsymbol{\sim}, 2.337(\boldsymbol{\sigma})\right.$, and $6.8 \mathrm{~g} \mathrm{~m}^{-3}(\boldsymbol{\sigma})$ for the thermophilic biofilter.

In our work, the average removal efficiencies of each compound differ for each biofilter. As an example the results obtained at different loads for the first two sections $(0-40 \mathrm{~cm})$ are summarized in Table I for the mesophilic and thermophlilic biofilters. These results show different degradation behaviors for each biofilter. This could be due to the effect of temperature and the variety of microbial populations developed in both units. Temperature effects in biofilters and biotrickling filters are expected to be relatively complex. It will affect the composition of the process culture, the metabolism, and both the rate of mass accumulation and the rate of pollutant degradation (Heitzer et al., 1991).

The apparent differences may be attributed in part to the variations of microbial dynamics in different sections and the corresponding specific activities and metabolic pathways utilized by the dominant strains involved in the BTEX degradation. Several authors reported VOC removal stratification along the filter bed. Lu et al. (2000) observed that the average removal fractions of benzene, toluene, ethylbenzene, and xylene in the upper half of a biotrickling filter were equal to $0.69,0.74,0.73$, and 0.75 , respectively. In a study of Namkoong et al. (2003), about $80-100 \%$ of the influent BTEX was removed in the lower half of the biofilter 
when the inlet concentration was less than $720 \mathrm{mg} \mathrm{BTEX} \mathrm{m}^{-3}$. In the concentration range of 5.9-13.8 $\mathrm{g}$ toluene $\mathrm{m}^{-3}$, about $70 \%$ of the pollutant was removed in the first half of a compost biofilter (Park, 2000). Two phenomena could take place: (1) there may be competition between microbial communities, and (2) there may be competition between substrates while the microbial populations are the same over the height of the column, but the easily biodegradable compounds are used first for the microbial metabolism.

\section{Carbon Dioxide Production}

In the biofiltration process, organic pollutants are aerobically degraded to water, carbon dioxide, and biomass. Therefore, the profile of carbon dioxide concentration in the gas phase at the inlet and the outlet of the biofilter provides useful information on the biofilter's performance. In Figure 6A, elimination capacities are presented along with the carbon dioxide production measured as the difference between the influent and effluent readings for both biofilters. In general, a similar trend was observed for both $\mathrm{EC}$ and $\mathrm{CO}_{2}$ production; an increase/decrease in the EC was accompanied by increase/decrease in the production of $\mathrm{CO}_{2}$. The maximum $\mathrm{CO}_{2}$ production rates were 169 and $211 \mathrm{~g} \mathrm{~m}^{-3} \mathrm{~h}^{-1}$ for the mesophilic and the thermophilic biofilter, respectively. Additionally, $\mathrm{CO}_{2}$ production percentages in each section versus BTEX elimination capacities have been plotted in Figure 6B and C. The percentage that each section of the filter bed contributes to the total was calculated from the ratio of $\mathrm{CO}_{2}$ produced in the individual section to the total $\mathrm{CO}_{2}$ produced in the bioreactor. Results for both biofilters show that the highest percentage of carbon dioxide produced was in the upper section $(0-20 \mathrm{~cm})$ when operating at a low inlet load. Furthermore, at high inlet loads the percentage of $\mathrm{CO}_{2}$ produced by the other sections became more significant. For example, under ambient temperature increasing the EC from 26 to $214 \mathrm{~g} \mathrm{~m}^{-3} \mathrm{~h}^{-1}$ caused a decrease of the $\mathrm{CO}_{2}$ production percentage in the upper section $(0-20 \mathrm{~cm})$ from 62.5 to $33.5 \%$ (Fig. 6B). The same trend was observed in the thermophilic biofilter, and increasing the EC up to $218 \mathrm{~g}$ $\mathrm{mS} 3 \mathrm{hS} 1$ decreased the $\mathrm{CO}_{2}$ percentage in the first section from $54.7\left(\mathrm{EC}=27 \mathrm{~g} \mathrm{~m}^{-3} \mathrm{~h}^{-1}\right)$ to $18.7 \%\left(\mathrm{EC}=218 \mathrm{~g} \mathrm{~m}^{-3} \mathrm{~h}^{-1}\right.$ ) (Fig. 6C). This behavior is similar to the trend observed before for the removal efficiencies at different bed heights (Fig. 5).

Also, in this work the observed production of carbon dioxide in the gas phase was lower than the theoretical one (data not shown). For the thermophilic biofilter, $\mathrm{CO}_{2}$ recoveries ranged from 60 to $40 \%$, while the discrepancy between theoretical and experimental values was much higher for the mesophilic reactor after day 93 of operation, and this was accompanied with a high growth rate (Table II). The possible reasons for this difference is that part of the BTEX compounds degraded was incorporated into biomass during microbial growth. Also some of the $\mathrm{CO}_{2}$ produced may have accumulated in the aqueous biolayer in the form of $\mathrm{HCOS}_{3}, \mathrm{H}_{2} \mathrm{CO}_{3}$, or $\mathrm{CO}_{3} \mathrm{~S}_{2}$. This discrepancy in the experimental and theoretical $\mathrm{CO}_{2}$ values in continuous bioreactors was observed by other investigators (Cox et al., 2001; Elmrini et al., 2004).

\begin{tabular}{|c|c|c|c|c|c|c|}
\hline & \multicolumn{3}{|c|}{ Mesophilic } & \multicolumn{3}{|c|}{ Thermophilic } \\
\hline & \multicolumn{3}{|c|}{ Inlet load $\left(\mathrm{g} \mathrm{m}^{-3} \mathrm{~h}^{-1}\right)$} & \multicolumn{3}{|c|}{ Inlet load $\left(\mathrm{g} \mathrm{m}^{-3} \mathrm{~h}^{-1}\right.$} \\
\hline & 36 & 90 & 165 & 35 & 88 & 173 \\
\hline Benzene & 42 & 3 & 4 & 100 & 97 & 31 \\
\hline Toluene & 100 & 87 & 72 & 100 & 87 & 78 \\
\hline Fthylbenzene & 100 & 88 & 71 & 78 & 37 & 2 \\
\hline$p$-xylene & 28 & 15 & 21 & 35 & 33 & 0 \\
\hline$m$-xylene & 86 & 76 & 55 & 78 & 46 & 13 \\
\hline$o$-xylene & 81 & 64 & 53 & 85 & 67 & 25 \\
\hline
\end{tabular}



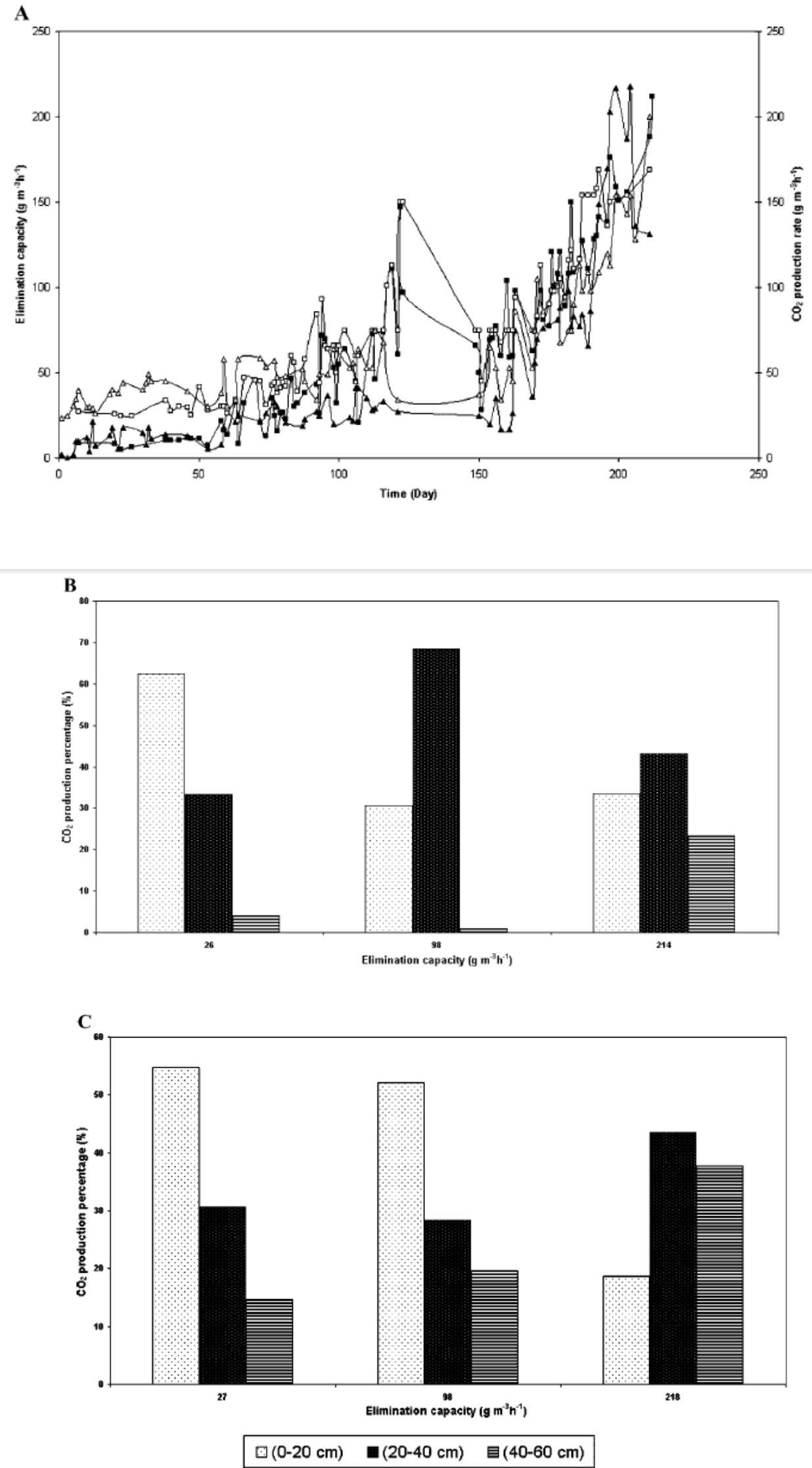

Figure 6. A: Elimination capacity of BTEX (closed symbol) and carbon dioxide production (open symboll) versus time for the mesophilic (square) and the thermophilic biofiter (triangle). B: Carbon dioxide production perc enta ges in different sections of the mesophilic biofilter versus BTEX elimination capacity. C: Carbon dioxide production perc enta ges in different sections of the thermophilic biofiter versus BTEX elimination capacity. 
Temperature and $\mathrm{pH}$ Variations

All bio-oxidation reactions are exothermic. Consequently the temperature profile across the biofilter is expected to rise from the water evaporation and metabolic heat production. Therefore the mean biofilter beds temperatures were monitored periodically. As shown in Figure 7A and B, in both biofilters the average bed temperature and the EC followed a similar trend. When the BTEX EC increased, the average bed temperature also increased. For example, the mesophilic biofilter's average bed temperature rose from 20.5 to $26.5^{\circ} \mathrm{C}$ with a corresponding average increase in the EC from 22 to $97 \mathrm{~g} \mathrm{~m}^{-3} \mathrm{~h}^{-1}$. Similarly, the thermophilic biofilter's temperature showed an average increase from 46 to 528C as the mean EC raised from 14 to $60 \mathrm{~g} \mathrm{~m}^{-3} \mathrm{~h}^{-1}$. It was proposed by Wu et al. (2006), studying p-xylene

removal from an air stream in a hybrid biofilter, that an increase in the filter bed's temperature was associated with an increase in the EC suggesting that more microorganisms grew and were involved in the biodegradation of greater quantity of pollutants. Simultaneously, increasing the bed temperature enhanced the activity of microorganisms which in turn improved the EC.

In addition, during the operation our two biofilters were regularly fed fresh nutrients. The $\mathrm{pH}$ of the drained liquid was recorded. It was initially 5.9 and due to the uptake of $\mathrm{NH}_{3}$ from the mediumby the microorganisms, a pH drop was expected. Acidification of the mesophilic filter was faster than for the thermophilic one, since its $\mathrm{pH}$ dropped below 3 in 92 days. On the other hand, the $\mathrm{pH}$ of the thermophilic biofilter dropped below 4 in 189 days. There was no adverse effect on the performance of the mesophilic reactor associated with this low $\mathrm{pH}$, while it was noticed that the thermophilic filter's EC was affected slightly by the decrease of $\mathrm{pH}$. Several authors reported a good biofilter performance at low pH. Aizpuru et al. (2001) studied the biofiltration of a mixture of volatile compounds using a peat biofilter. They reached a maximum EC of $120 \mathrm{~g} \mathrm{VOC} \mathrm{m}^{-3} \mathrm{~h}^{-1}$ even under acidic conditions ( $\mathrm{pH}$ 3.5-4.5). Similarly, Kennes et al. (1996) observed during aromatic compounds treatment that elimination efficiencies obtained at $\mathrm{pH} 4.5$ were as high as those obtained at neutral $\mathrm{pH}$. A high activity at low $\mathrm{pH}$ is often associated to fungal growth (Kennes and Veiga, 2004). This was also confirmed by SEM observations in this study.

Table II. Average biomass and protein contents for mesophilic and thermophilic reactors.

\begin{tabular}{|c|c|c|c|c|}
\hline \multirow[b]{2}{*}{ Day } & \multicolumn{2}{|c|}{ Mesophilic } & \multicolumn{2}{|c|}{ Thermophilic } \\
\hline & Dry biomass ( $\left.\mathrm{g} \mathrm{g}_{\text {support }}^{-1}\right)$ & Protein content ( $\mathrm{mg} \mathrm{g} \mathrm{g}_{\text {support }}^{-1}$ ) & Dry biomass ( $\left.\mathrm{g} \mathrm{g}_{\text {support }}^{-1}\right)$ & Protein content (mg g gapport \\
\hline 0 & 0.031 & 2.516 & 0.029 & 2.500 \\
\hline 23 & 0.042 & 2.970 & 0.041 & 1.555 \\
\hline 93 & 0.059 & 2.155 & 0.076 & 3.388 \\
\hline 170 & 0.263 & 5.350 & 0.09 & 4.033 \\
\hline 210 & 0.300 & 3.270 & 0.114 & 5.233 \\
\hline
\end{tabular}



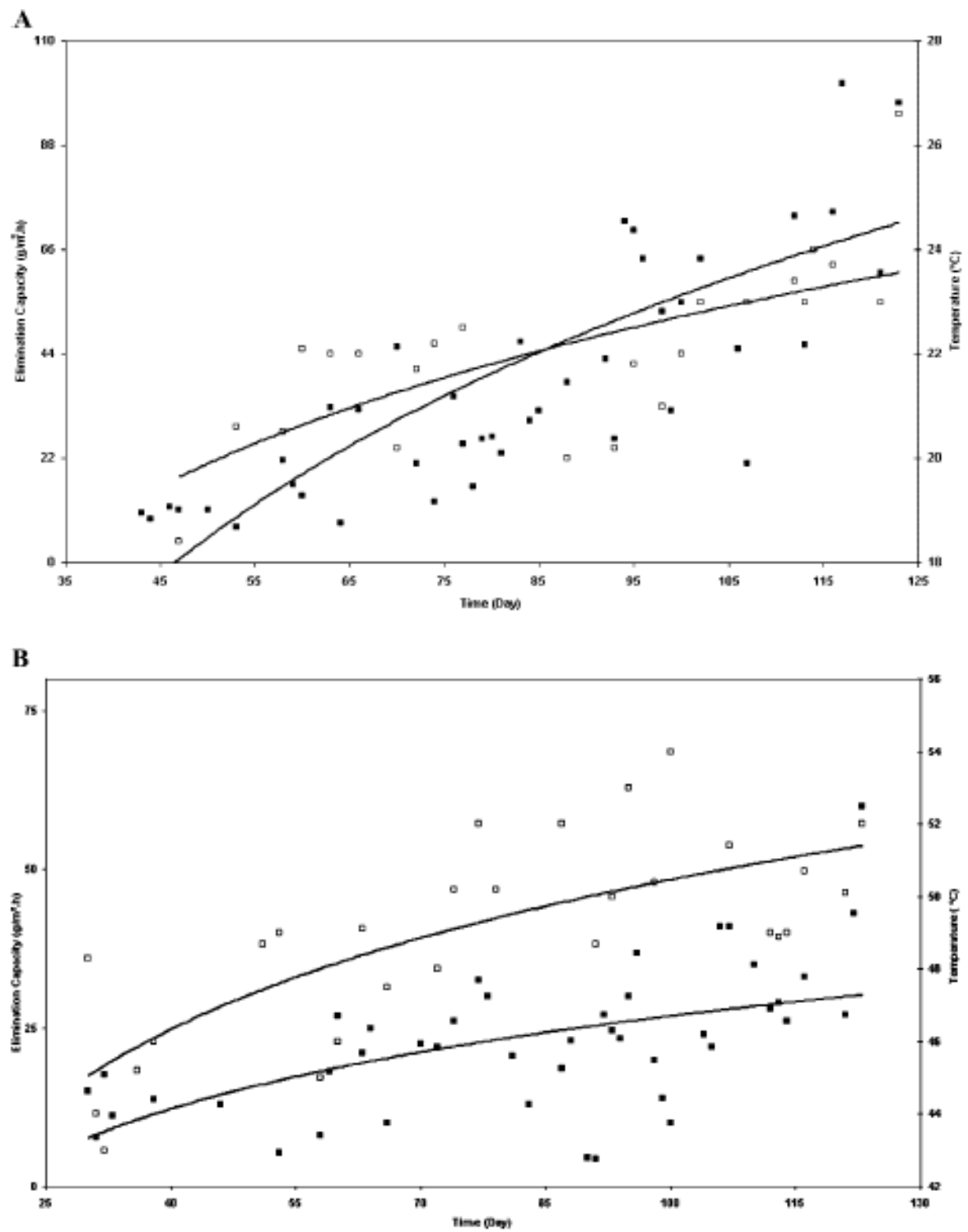

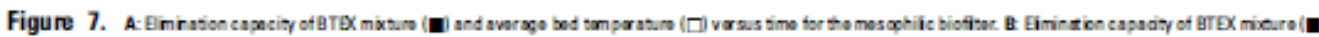

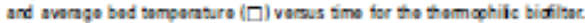

\section{Scanning Electron Microscopy}

Samples of the packing materials were taken from both reactors on days 110 and 200 of operation and were observed under SEM. Figure 8A-D clearly shows that for the mesophilic biofilter mostly fungi colonized the packing material. This high presence of filamentous fungi with a dark gray color typical of Exophiala spp. (Fig. 8A and B), and the biofilm extent in the mesophilic reactor could explain the higher pressure drop obtained in comparison to the bacterial reactor. On the contrary, bacterial colonies were more dominant in the thermophilic biofilter both in the higher and lower section of the biofilter (Fig. 8C and D). The dominant presence of fungi in the mesophilic reactor, explain the high activity of that system at low $\mathrm{pH}(\mathrm{pH} 3)$. More experiments are being carried out on identification of the microbial populations within the two biofilters and on their role in term of BTEX biodegradation. 
A

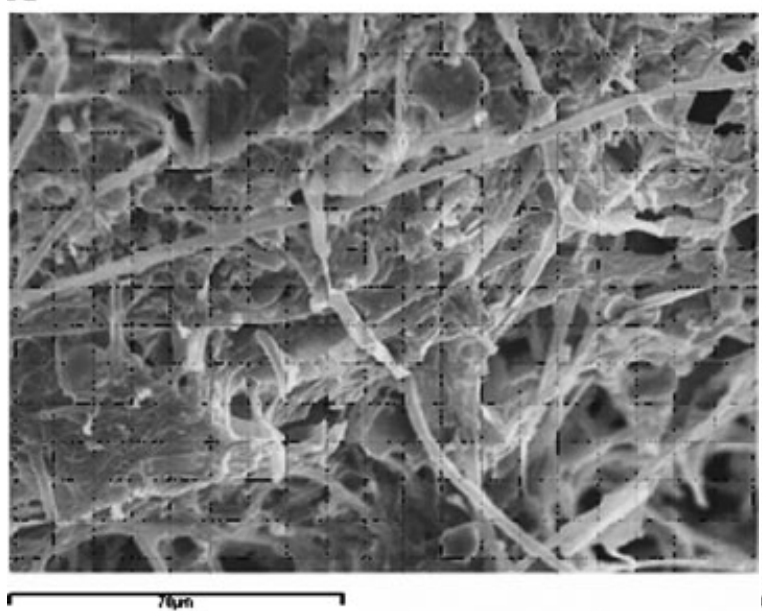

C

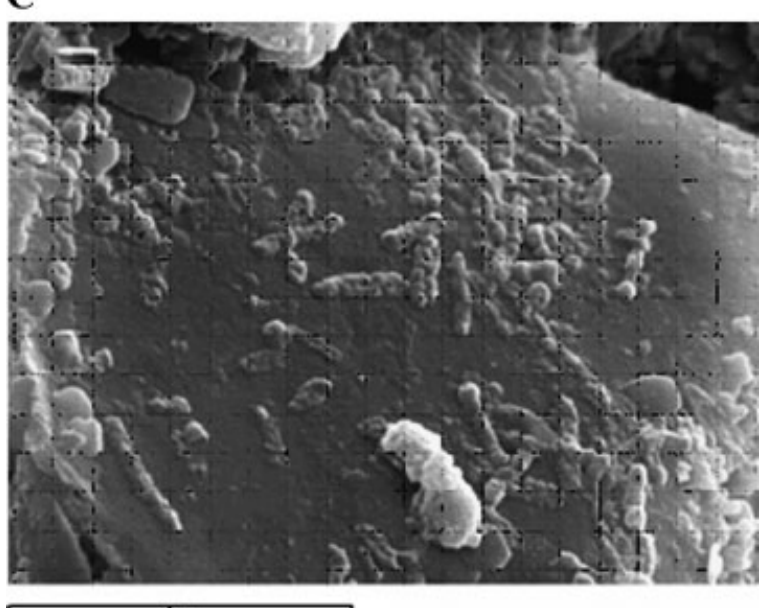

B

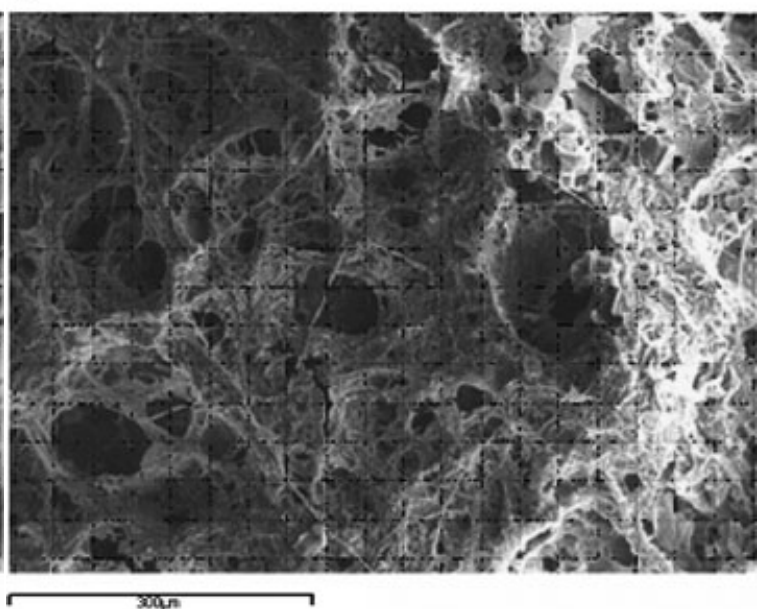

D

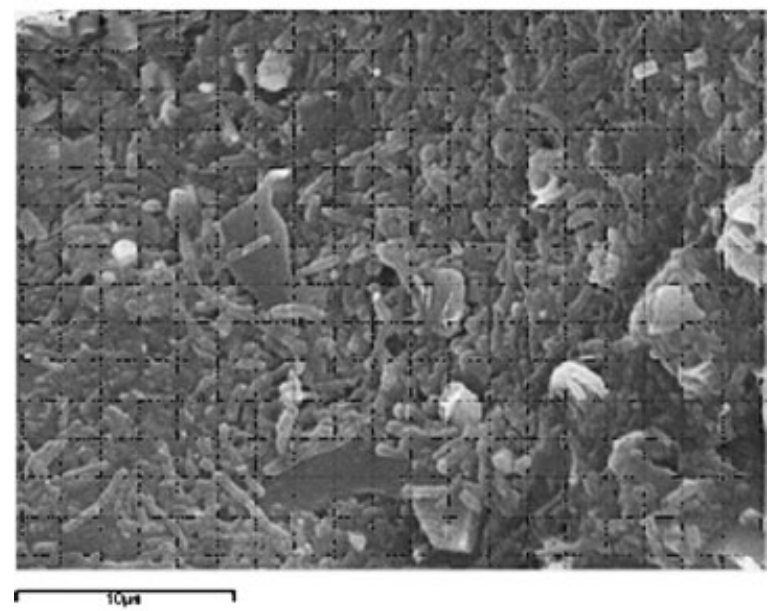

Figure 8. A: Scanning electron micrograph $(3,750 x)$ of the upper section of the mesophilic biofilter after 100 days of operation. B: Scanning electron micrograph $(51,100 x)$ of the lower section of the mesophilic biofilter after 200 days of operation. C: Scanning electron micrograph $(6,000 \times)$ of the upper section of the thermophilic biofilter after 200 days of operation. D: Scanning electron micrograph $(3,500 \times)$ of the lower section of the thermophilic biofilter after 200 days of operation.

Pressure Drop and Biomass Accumulation

Pressure drop across the filter bed is an important parameter because it can give an indication of the compaction state of the filter bed and the excess biomass accumulation. It was observed that there is a gradual pressure build up with time due to generation and accumulation of biomass with a reduction in the bed's void fraction. In this study, pressure drop increased slightly faster in the mesophilic than in the thermophilic reactor. It recorded a pressure drop of $11 \mathrm{~mm} \mathrm{H}_{2} \mathrm{O}$ at day 205 of operation, in comparison to 6 $\mathrm{mm} \mathrm{H}_{2} \mathrm{O}$ for the thermophilic reactor at the same day of operation. Wright et al. (1997) reported that the pressure drop of a compost biofilter was less than $10 \mathrm{~mm} \mathrm{H}_{2} \mathrm{O}$ over a $1.8 \mathrm{~m}$ bed height after 250 days of operation. In the same manner Namkoong et al. (2003) observed that a pressure drop of $60 \mathrm{~mm}$ H2O over $1 \mathrm{~m}$ did not cause significant operational problems. Thus biofiltration may still show high removal efficiencies of VOCs in these pressure drop ranges. An increase in pressure drop was primarily due to bed compaction caused by the accumulation of biomass, and compression of the filter materials. Biomass dry content and protein content for both biofilters were compared and are summarized in Table II. In the thermophilic biofilter biomass accumulation reached a value of $0.114 \mathrm{~g} g_{\text {support }}^{-1}$ after 210 days of operation. On the other hand, a high increase in the biomass content was observed after day 93 for the mesophilic reactor, where it increased from 0.059 to $0.300 \mathrm{~g} g_{\text {support }}^{-1}$ between days 93 and 210. Despite the fact that biomass accumulation under high temperature 
was significantly lower than in the ambient temperature reactor, a comparable BTEX elimination rate was obtained in both reactors. Therefore the higher biomass accumulation observed under mesophilic condition did not result in higher pollutant elimination. This agrees with observations made by other authors (Okkerse et al., 1999), which indicate that the majority of the biomass in a biofilter is inactive. Also, other authors recently reported less biomass formation under thermophilic than under mesophilic conditions in biotrickling filters, while similar or even higher removals could be reached at the highest temperature (Luvsanjamba et al., 2007). On the other hand, the protein content in both biofilters increased with time. After 170 days of operation, the protein content increased up to 5.35 and $4 \mathrm{mg}$ $g_{\text {support }}^{-1}$ in the mesophilic and thermophilic reactors, respectively. Although, for the mesophilic biofilter the protein content decreased after 170 days of operation to reach $3.27 \mathrm{mg} g_{\text {support }}^{-1}$ on day 210 . Furthermore, the lower biomass yield observed for the high temperature biofilter could be attributed to various phenomena such as increased maintenance energy requirements and temperature-induced growth uncoupling (Cox et al., 2001). No attempts were made in the current study to determine the metabolic pathways for different compounds which could be associated with different consortia.

\section{Conclusions}

In conclusion our studies demonstrate that it was possible to treat high loads of BTEX compounds under mesophilic and thermophilic conditions, using biofilters packed with perlite as a carrier material. Few reports studied the treatment of VOCs under high temperature, this work display the possibility of using thermophilic biofilters for such a treatment, hence it could form the basis for future development of industrial scale biofilters. The thermophilic showed a higher EC and lower pressure drop than the mesophilic one. A recalcitrant compound as benzene was much better removed under thermophilic conditions than in the mesophilic reactor. Also, it could be more interesting to know about the microbial populations within each reactor as a potential biocatalyst for BTEX degradation under extreme conditions; low $\mathrm{pH}$ and/or low relativehumidity.

The present research was funded by the Spanish Ministry of Educationand Science (project CTM 2004-0557-TECNO). The post-doctoral research of B.T.M was financed by that same Ministry.

\section{References}

Aizpuru A, Malhautier L, Roux JC, Fanlo JL. 2001. Biofiltration of a mixture of volatile organic emissions. J Air Waste Manage 51:1662-1670.

Al-Awadhi N, Egli T, Hamer G, Wehrli E. 1989. Thermotolerant and thermophilic solventutilizing methylotrophic aerobic bacteria. Syst Appl Microbiol 11:207-216.

Allen DG, Fulthorpe RR, Farhana L. 2000. Thermophilic biofiltration of volatile organic compounds. In: Proceedings of the 93rd annual meeting and exhibition air and waste management association, Air and Waste Management Association: Pittsburgh: PA.

Alvarez PJJ, Vogel TM. 1991. Substrate interactions of toluene, and para- xylene during microbial degradation by pure cultures and mixed culture aquifer slurries. Appl Environ Microbiol 57:2981-2985. 
Arnold M, Reittu A, von Wright A, Martikainen PJ, Suihko ML. 1997. Bacterial degradation of styrene in waste gases using a peat filter. Appl Microbiol Biotechnol 48:738744.

Bibeau L, Kiared K, Brzezinski R, Viel G, Heitz M. 2000. Treatment of air polluted with xylenes using a biofilter reactor. Water Air Soil Pollut 118:377-393.

Bradford MM. 1976. A rapid and sensitive method for the quantitation of microgram quantities of protein utilizing the principle of protein-dye binding. Anal Biochem 72:248254.

Characklis WG, Mcfeters GA, Marshall KC. 1991. Physiological ecology in biofilm systems. In: Characklis WG, Marshall KC, editors. Biofilm, New York: Wiley. pp 341-394.

Chen CI, Taylor RT. 1995. Thermophilic biodegradation of BTEX by two Thermus species. Biotechnol Bioeng 48:614-624.

Cox HHJ, Moerman RE, van Baalen S, van Heiningen WNM, Doddema HJ, Harder W. 1997. Performance of a styrene-degrading biofilter containing the yeast Exophiala jeanselmei. Biotechnol Bioeng 53:259-266.

Cox HHJ, Zarook TS, Shareefdeen M, Deshusses MA. 2001. Thermophilic biotrickling filtration of ethanol vapors. Environ Sci Technol 35:2612-2619.

De Nevers N. 1995. Air pollution control engineering. Singapore: McGraw- Hill. pp 441-461. Deeb RA, Alvarez-Cohen L. 1999. Temperature effects and substrate interactions during aerobic biotransformation of BTEX mixtures by toluene-enriched consortia and Rhodococus rhodochrous. Biotechnol Bioeng 62:226-236.

Dehghanzadeh R, Torkian A, Bina B, Poormoghaddas H, Kalantary A. 2005.Biodegradation of styrene laden waste gas stream using a compostbased biofilter Chemosphere. 60:434-439.

Deshusses MA, Johnson CT, Hohenstein GA, Leson G. 1999. Biofiltration of high loads of ethyl acetate in the presence of toluene. J Air Waste Manage Assoc 49:973-979.

Elmrini H, Bredin Z, Shareefdeen M, Heitz M. 2004. Biofiltration of xylene emissions: Bioreactor response to variations in the pollutant inlet concentration and gas flow rate. Chem Eng J 100:149-158.

Gabaldon C, Martinez-Soria V, Martin M, Marzal P, Penya-Roja JM, Alvarez-Hornos J. 2006. Removal of TEX vapours from air in a peat biofilter: Influence of inlet concentration and inlet load. J Chem Technol Biotechnol 8:322-328.

Heitzer A, Kohler HPE, Reichert P, Hamer G. 1991. Utility of phenomenological models for describing temperature dependence of bacterial growth. Appl Environ Microbiol 57:26562665.

Heslinga DC, Van Groenestijn JW. 1997. Thermophilic biological waste gas cleaning. In: Biological waste gas cleaning. Proceedings of an international symposium: The Netherlands: Maastricht. pp 353-358.

Hester RE, Harrison RM. 1995. Volatile organic compounds in the atmosphere. United Kingdom: The Royal Society of Chemistry.

Jin Y, Veiga MC, Kennes C. 2005. Bioprocesses for the removal of nitrogen oxides from polluted air. J Chem Technol Biotechnol 80:483-494.

Jin Y, Veiga MC, Kennes C. 2007. Fungal biofiltration of a-pinene: Effects of temperature, relative humidity, and transient loads. Biotechnol Bioeng 96:433-443.

Jorio H, Kiared K, Brzezinski R, Viel G, Heitz M. 1998. Treatment of air polluted with High concentrations of toluene and xylene in a pilot scale biofilter. J Chem Technol Biotechnol 73:183-196.

Kamarthi R, Willingham RT. 1994. Bench-scale evaluation of air pollution control technology based on a biological treatment process. In: Proceedings of the 87th Annual Meeting of the Air and Waste Management Association, Cincinnati, OH. 
Kennes C, Veiga MC. 2001. Bioreactors for waste gas treatment. Dordrecht, The Netherlands: Kluwer Academic Publishers.

Kennes C, Veiga MC. 2004. Fungal biocatalysts in the biofiltration of VOCpolluted air. J Biotechnol 113:305-319.

Kennes C, Cox HHJ, Doddema HJ, Harder W. 1996. Design and performance of biofilters for the removal of alkylbenzene vapors. J Chem Technol Biotechnol 66:300-304.

Leson G, Winer AM. 1991. Biofiltration: An innovative air pollution control technology for VOC emissions. J Air Waste Manage Assoc 41:1045- 1054.

Lu C, Lin MR, Chu C. 1999. Temperature effects of trickle-bed biofilter for treating BTEX vapors. J Environ Eng 125:775-779.

Lu C, Chu W, Lin M. 2000. Removal of BTEX vapor from waste gases by a trickle bed biofilter. J Air Waste Manage Assoc 50:411-417.

Luvsanjamba M, Sercu B, Kerstész S, Van Langenhove H. 2007.

Thermophilic biotrickling filtration of a mixture of isobutyraldehyde and 2-pentanone. $\mathrm{J}$ Chem Technol Biotechnol 82:74-80.

Matteau Y, Ramsay B. 1997. Active compost biofiltration of toluene.

Biodegradation 8:135-141.

Moe WM, Qi B. 2004. Performance of a fungal biofilter treating gas-phase solvent mixtures during intermittent loading. Water Res 38:2259- 2268.

Namkoong W, Park JS, VanderGheynst JS. 2003. Biofiltration of gasoline vapor by compost media. Environ Pollut 121:181-187.

Oh YS, Bartha R. 1997. Construction of a bacterial consortium for the biofiltration of benzene. J Microbiol Biotechnol 13:627-632.

Oh YS, Shareefdeen Z, Baltzis BC, Bartha R. 1994. Interactions between benzene, toluene and p-xylene (BTX) during their biodegradation. Biotechnol Bioeng 44:533-538.

Okkerse WJH, Ottengraf SPP, Osinga-Kuipers B, Okkerse M. 1999. Biomass accumulation and clogging in biotrickling filters for waste gas treatment. Evaluation of a dynamic model using dichloromethane as a model pollutant. Biotechnol Bioeng 63:418-430.

Oritz I, Morales M, Gobbee C, Revah S, Guerrero VM, Auria R. 1998. Biofiltration of gasoline VOCs with different support media. In: Proceedings of 91st Annual Meeting and Exhibition, A\&WMA, San Diego, CA. 14-18 June.

Park YJ. 2000. Removal of toluene by granular activated carbon biofilter. Master thesis, Konkuk University, Korea. Smith MA. 1990. The biodegradation of aromatic hydrocarbons in bacteria Biodegradation. 1:191-206.

Strauss JM, Riedel KJ, du Plessis CA. 2004. Mesophilic and thermophilic BTEX substrate interactions for a toluene-acclimated biofilter. Appl Microbiol Biotechnol 64:855-861.

Torkian A, Dehghanzadeh R, Hakimjavadi M. 2003. Biodegradation of aromatic hydrocarbons in a compost biofilter. J Chem Technol Biotechnol 78:795-801.

van Groenestijn JW, Liu JX. 2002. Removal of alpha-pinene from gases using biofilters containing fungi. Atmos Environ 36:5501-5508.

Van Lith C, Leson G, Michelson R. 1997. Evaluating design option for biofilters. J Air Waste Manage Assoc 47:37-48.

Veiga MC, Kennes C. 2001. Parameters affecting performance and modelling of biofilters treating alkylbenzene-polluted air. Appl Microbiol Biotechnol 55:254-258.

Webster TS, Devinny JS, Torres EM, Basrai SS. 1995. Control of air emissions from POTWs using biofiltration. In: Hinchee RE, Sayles GD, Skeen RS, editors. Biological Unit Processes for Hazardous Waste Treatment, In Situ and On Site Bioreclamation Symposium. Columbus, OH: Battelle Press. pp 227-234. 
Woertz JR, Kinney KA, McIntosh NDF, Szaniszlo PJ. 2001. Removal of toluene in a vaporphase bioreactor containing a strain of the dimorphic black yeast Exophiala lecaniicorni. Biotechnol Bioeng 75: 550-558.

Wright WF, Schroeder ED, Chang DPY, Romstad K. 1997. Performance of a pilot-scale compost biofilter treating gasoline vapor. J Env Eng 123:547-555.

Wu D, Quan X, Zhao Y, Chen S. 2006. Removal of p-xylene from an air stream in a hybrid biofilter. J Hazard Mater 136:288-295.

Yoon IK, Park CH. 2002. Effects of gas flow rate, inlet concentration and temperature on biofiltration of volatile organic compounds in a peatpacked biofilter. J Biosci Bioeng 93:165169. 